\title{
ALGUMAS INCIDÊNCIAS CONSTITUCIONAIS DA INSTITUCIONALIZAÇÃO DA UNIÃO ECONÔMICA E MONETÁRIA
}

\author{
António José Avelãs Nunes*
}

1. Até recentemente, não existia em Portugal uma tradição de autonomia do banco central. Ao invés, o Banco de Portugal era considerado um instrumento de execução das políticas do governo.

* O autor é professor catedrático da Faculdade de Direito de Coimbra; doutorou-se com uma tese sobre "Industrialização e Desenvolvimento - A Economia Política do "Modelo Brasileiro de Desenvolvimento",; foi agraciado pelo Presidente da República Federativa do Brasil com a Ordem do Rio Branco; em 2001, foi observador estrangeiro convidado na Comissão da CAPES para a Avaliação dos Cursos de Pós-Graduação em Direito (Mestrado e Doutorado); tem proferido palestras e aulas magnas em várias Universidades brasileiras; é membro correspondente da Academia Brasileira de Direito Constucional.

O texto que aqui se publica é, com ligeiras alterações, o que serviu de base à comunicação apresentada no IV Simpósio Nacional de Direito Constitucional, realizado em Curitiba pela Academia Brasileira de Direito Constitucional (14-16 de outubro de 2002).
SUMÁRIO: Autonomia do Banco de Portugal. • Aspectos Constitucionais. $\bullet$ Eurossistema e Banco Central Europeu $\bullet$ Estrutura Jurídica, Objetivos, Competências e Atribuições • "Soberania Comunitária” e reflexões sobre a atuação do Banco de Portugal $\bullet$ Políticas Econômicas da Comunidade Européia e Controle Democrático.

A Lei Orgânica (LO) de 1990 (DL n. ${ }^{\circ}$ 337/ 90, de 30 de outubro) veio, pela primeira vez, atribuir ao Banco de Portugal (BP) uma certa margem de autonomia, em termos que iam além do quadro constitucional então em vigor.

A Constituição da República Portuguesa (CRP), na versão originária de 1976, mantida na revisão de 1982, dizia, no art. 105, n. ${ }^{\circ}$, que "o Banco de Portugal, como banco central, tem o exclusivo da emissão de moeda e, de acordo com o Plano e as directivas do Governo, colabora na execução das políticas monetária e financeira".

Após as ligeiras alterações introduzidas pela Lei Constitucional (LC) n. ${ }^{\circ} 1 / 89$, o art. 105 CRP passou a ter a seguinte redação: "o Banco de Portugal, como banco central, tem o exclusivo da emissão de moeda e colabora na execução das políticas monetária e financeira, 
de acordo com a Lei do Orçamento, os objectivos definidos nos planos e as directivas do Governo."

É patente o reduzido grau de autonomia conferido pela CRP ao banco central português. Este não tinha competência para definir nem tinha o direito de colaborar na definição da política monetária. Cabia-lhe tão-só colaborar na execução das políticas monetária e financeira. Do texto constitucional resultava que a execução da política monetária cabia, em primeira linha, ao Governo, com o qual o BP tinha o direito (e o dever) de colaborar.

Desse texto resultava também a natureza subordinada da política monetária e da ação do BP. Aquela não podia afirmar objetivos próprios, que valessem por si, acima dos objetivos gerais da política econômica; o Banco devia subordinar-se, no exercício das suas competências, aos objetivos definidos nos planos, na lei do Orçamento e nas directivas do Governo.

Ora, os planos são elaborados pelo Governo, de acordo com o seu programa, cabendo à Assembléia da República (AR) aprovar as grandes opções correspondentes a cada plano (arts. 92, 93 e 164, al. h) CRP). Os objetivos dos planos são os referidos no art. $91 \mathrm{CRP}$ (entre os quais não é sequer referida expressamente a estabilidade monetária): "promover o crescimento económico, o desenvolvimento harmonioso de sectores e regiões, a justa repartição individual e regional do produto nacional, a coordenação da política econômica com as políticas social, educacional e cultural, a preservação do equilíbrio ecológico, a defesa do ambiente e a qualidade de vida do povo português." Os planos anuais têm a sua expressão financeira no Orçamento do Estado
(OE), cuja aprovação é da competência da AR (art. 164, al. h) CRP).

Tal como resultou da revisão de 1989 , a CRP não reconhecia, pois, ao banco central português qualquer competência para definir ou executar políticas cujos objetivos não fossem os apontados nos planos e no OE pelos órgãos políticos para tanto competentes (a AR e o Governo). A este cabia, aliás, o direito de emitir diretivas definidoras de objetivos de política às quais deveria subordinar-se a ação do BP (art. 105 CRP, in fine).

Algo diferente desse figurino constitucional de 1989 foi o estatuto do BP consagrado na Lei Orgânica de 1990.

Com inteira razão, o preâmbulo dessa lei sublinhava não ser função primordial do BP (como dos bancos centrais em geral) a função emissora, mas a função de regulação monetária e cambial e de defesa da estabilidade do sistema financeiro e do sistema de pagamentos.

No pressuposto de que as opções tomadas no âmbito do processo de integração européia conduziriam à criação de uma estrutura européia de banco central e à adoção de uma política monetária e de uma política cambial únicas, a LO privilegiava "as exigências de estabilidade monetária que subjazem a este projecto" (de união econômica e monetária no seio da CE), assim se justificando "a elevação do grau de autonomia do Banco na condução da política monetária" e a consagração de certos princípios (nomeadamente o consagrado no art. 27 LO) que, se pretendia, funcionassem como "garante da autonomia da política monetária".

$\mathrm{O}$ art. $3 .^{\circ}$ LO qualificava o BP como o Banco Central da República Portuguesa e atribuía-lhe o objetivo de assegurar o equilíbrio monetário interno e a solvência 
exterior da moeda. Ao BP reconhecia-se (art. 18 LO) competência para colaborar na definição da política monetária (o que ia além do texto constitucional) e competência para executar (em vez do dever de colaborar na execução de) a política monetária e cambial (definida pelo Governo com a colaboração do Banco). Mas o preceito em causa salientava que, na execução das políticas, o BP deveria ter em conta as orientações do Governo.

Ao BP caberia também aconselhar o Governo, não só no domínio da política monetária, mas também em matéria financeira e fiscal. Dadas a (crescente) interligação dos mercados monetário, financeiro e cambial e a (crescente) interdependência das políticas monetária, financeira e cambial, essa capacidade do Banco poderia permitir a conveniente articulação entre o Governo e o BP, dando a este a oportunidade de fazer ouvir a sua opinião em questões não incluídas na sua esfera de competência (política orçamental; gestão e financiamento da dívida pública; regras de funcionamento e gestão corrente do mercado de capitais e das bolsas de valores).

Mas o sinal mais claro da autonomia que se quis conceder ao BP resultava do disposto no art. $27 \mathrm{LO}$, que proibia expressamente ao Banco:

$1^{\circ}$ ) a concessão de crédito ao Estado e a outras pessoas coletivas de direito público;

2.') a garantia de quaisquer obrigações do Estado, de serviços dele dependentes ou de outras pessoas coletivas de direito público, bem como a realização de pagamentos de conta de qualquer deles, quando não existissem no Banco fundos que lhes pertencessem e que para tal fim estivessem imediatamente disponíveis.
O Estado ficava, em grande medida, impossibilitado de financiar as despesas públicas pela via monetária, caminhando-se, desse modo, no sentido de autonomizar a política monetária da política orçamental.

Ao Estado restava apenas:

a) possibilidade de obter, por meio de crédito concedido pelo Banco, os meios necessários à comparticipação no capital de organismos internacionais com atividade principal nos domínios monetário, financeiro e cambial (art. 25 LO);

b) a possibilidade de recorrer (bem como as Regiões Autônomas) a uma conta gratuita aberta no Banco, cujo saldo devedor não poderia exceder $10 \%$ das respectivas receitas correntes cobradas no último ano (art. 26 LO);

c) a possibilidade de tomada firme de Bilhetes do Tesouro pelo BP, por acordo entre o Banco e o Ministério das Finanças, desde que observados os limites legais, nomeadamente os decorrentes da lei do Orçamento (art. 27, n..$^{\circ}$, in fine, LO);

d) a possibilidade de o BP comprar títulos do Estado Português, no âmbito da execução da política monetária e cambial (art. $35, .^{\circ}$ 1, al. b) LO).

Quer dizer: o financiamento do Tesouro pelo BP passou a depender do acordo do Banco e passou a consistir unicamente na tomada de títulos da dívida pública no mercado primário (de curto prazo ou de médio e longo prazo), títulos com os quais o Banco constituía a sua carteira, que utilizaria depois (especificamente, os Bilhetes do Tesouro) para as intervenções do Banco no mercado aberto, vendendo-os ou readquirindo-os no mercado secundário. 
2. O Tratado da União Européia (TUE), aprovado no Conselho Europeu de 10 de dezembro de 1991 e assinado em Maastricht em 7 de fevereiro de 1992, decidiu a instituição da União Econômica e Monetária (UEM), com a criação de um Sistema Europeu de Bancos Centrais (SEBC) e de um Banco Central Europeu (BCE), e a adoção de uma política monetária única e de uma moeda única (o euro). A partir de Maastricht, o "Protocolo Relativo aos Estatutos do Sistema Europeu de Bancos Centrais e do Banco Central Europeu" passou a fazer parte integrante do Tratado que Institui a Comunidade Europeia (TCE).

Pela primeira vez na história, vários grandes países (Alemanha, Espanha, França, Itália) aceitam abdicar da sua moeda e pela primeira vez uma união monetária é constituída sem existir previamente uma união política, num espaço econômico que, reconhecidamente, está longe de satisfazer as exigências de uma zona monetária ótima.

Sustentam alguns autores que, existindo na zona euro estruturas produtivas com graus de desenvolvimento muito diferentes, níveis diferenciados de desenvolvimento econômico e social e muito escasssa mobilidade geográfica da mão-de-obra, e, sobretudo, não sendo a União Européia (UE) um Estado federal e não dispondo a CE de um orçamento federal com suficiente capacidade redistributiva, teria sido mais prudente aprofundar primeiro as políticas que melhorassem a coesão econômica e social e edificassem estruturas econômicas mais uniformes e só depois avançar com a criação da moeda única (Robert Solow, Público, 14 de setembro de 2002).

Advertem outros para o fato de uma política monetária única repercutir de modo diferente em países diferentes, podendo constituir-se, nas condições anteriormente referidas, em fator de retardamento da convergência real ou mesmo de agravamento do fosso existente entre os membros da união monetária.

A verdade, porém, é que, apesar das reticências dos teóricos, a decisão de criar a moeda única foi adiante, talvez por ter sido, mais do que uma decisão motivada pela necessidade de criar um instrumento monetário e econômico, um projeto político resultante de um acordo entre a França e a Alemanha, destinado a enfrentar a nova realidade política européia na seqüência da queda do muro de Berlim e da reunificação da Alemanha.

2.1. O SEBC é constituído pelo BCE e pelos bancos centrais nacionais dos quinze países da Comunidade Européia (CE).

Diferentemente do que acontece com o BCE e com os bancos centrais nacionais (BCN), o SEBC não tem personalidade jurídica nem órgãos de decisão próprios, sendo os seus objetivos prosseguidos pelo BCE e pelos bancos centrais nacionais dos quinze países signatários do TUE.

Para facilitar a compreensão da estrutura dos bancos centrais da área do euro, o Conselho do BCE deliberou a adoção do termo Eurossistema para se referir à estrutura (não dotada de personalidade jurídica, tal como o SEBC) composta pelo BCE e pelos bancos centrais nacionais dos doze países que adotaram o euro como moeda, transferindo para o Eurossistema a respectiva soberania no domínio da política monetária (Alemanha, Áustria, Bélgica, Espanha, Finlândia, França, Grécia, Irlanda, Itália, Luxemburgo, Países Baixos e Portugal). 
Em termos genéricos, diremos que o objetivo primordial do Eurossistema é o de manter a estabilidade dos preços, no quadro de uma economia de mercado aberta e de livre concorrência, cabendo-lhe, nos termos do Tratado, as seguintes atribuições fundamentais:

a) a definição e execução da política monetária da área do euro;

b) a realização de operações cambiais;

c) a detenção e gestão das reservas cambiais oficiais dos Estados-Membros;

d) a promoção do bom funcionamento dos sistemas de pagamentos;

e) a emissão de notas de banco com curso legal na área do euro;

f) a aprovação do limite de emissão de moedas metálicas de euros pelos EstadosMembros cuja moeda é o euro.

Ao Eurossistema cabe também:

a) contribuir para a condução regular das políticas prosseguidas pelas autoridades competentes relativamente à supervisão prudencial das instituições de crédito e estabilidade do sistema financeiro;

b) ser consultado sobre qualquer proposta de ato comunitário ou sobre qualquer projeto de disposição legal nos domínios das suas atribuições;

c) compilar a informação estatística necessária para o cumprimento das atribuições que lhe estão cometidas;

d) ser representado no domínio da cooperação internacional e participar em instituições monetárias internacionais.

2.2. O BCE é o núcleo do Eurossistema, cabendo-lhe as competências correspondentes à responsabilidade de garantir o cumprimento, pela sua própria atuação ou por meio da ação dos bancos centrais nacionais, das atribuições cometidas ao Eurossistema.

Caso único na história dos bancos centrais em todo o mundo, o estatuto do BCE não consta de lei ordinária, não é objeto de um instrumento de direito comunitário nem sequer está plasmado no texto de uma Constituição; antes, é parte integrante de um tratado internacional que envolve quinze países (o próprio BCE fala de um "tratado com estatuto constitucional"). A alteração desse estatuto, se vier a revelar-se necessária, pode constituir um problema de difícil solução.

Um outro ponto de excessiva rigidez é o que resulta da al. b) do n. $^{\circ} 2$ do art. 112 TCE, nos termos da qual o Presidente, o VicePresidente e os Vogais da Comissão Executiva são nomeados, dentre personalidades de reconhecida competência, de comum acordo, pelos Governos dos Estados-Membros, em nível de Chefes de Estado ou de Governo, sob recomendação do Conselho e após este ter consultado o PE e o Conselho do BCE.

Os problemas surgidos a propósito da nomeação do primeiro Presidente (cuja solução significou logo a violação do estatuto de independência do Presidente do BCE) ilustram bem as dificuldades inerentes a esta solução. ${ }^{1}$ Com o alargamento da CE a

\footnotetext{
${ }^{1}$ Segundo noticiaram os jornais, a França aceitou a nomeação do atual Presidente, imposto pela Alemanha, com a condição de este resignar ao cargo a meio do mandato, para que a presidência do BCE passe então a ser ocupada por outra personalidade designada pela França.

Como já se sabia, todos os Estados-Membros da CE são iguais, mas uns são claramente mais iguais do que outros. Depois desse episódio, como continuar a defender que os responsáveis pela direção do BCE são independentes do poder político, não podendo receber instruções ou injunções de qualquer tipo por parte de órgãos do poder político, comunitários ou nacionais?
} 
25 membros, o comum acordo será muito mais difícil de obter. Esta a razão que leva o $\mathrm{PE}$ a defender outro procedimento de escolha (talvez atribuindo essa competência ao PE).

A decisão de instalar a sede do BCE em Frankfurt passou também a ser matéria regulada no TCE, por meio de um Protocolo que figura como Anexo ao Tratado, por força do Tratado de Amsterdã.

O BCE é dotado de personalidade jurídica nos termos do direito internacional público, tendo capacidade para celebrar acordos dos domínios das suas atribuições e para participar nos trabalhos de organizações internacionais (FMI, OCDE, Banco de Pagamentos Internacionais).

Os órgãos de decisão do BCE são o Conselho e a Comissão Executiva.

Enquanto houver Estados-Membros da Comunidade Européia que não integram o Eurossistema (neste momento, o Reino Unido, a Dinamarca e a Suécia), funcionará também o Conselho Geral, composto pelo Presidente e Vice-Presidente do BCE e pelos governadores dos BCN de todos os EstadosMembros da CE. O Conselho Geral é necessário para acompanhar a preparação dos bancos centrais nacionais que estão fora da área do euro para uma eventual futura participação no Eurossistema, constituindo um fórum adequado para o estreitamento da cooperação entre esses bancos centrais nacionais e o Eurossistema.

O Conselho do BCE é o órgão máximo na hierarquia dos poderes de gestão do BCE. Integram-no, além dos seis membros da Comissão Executiva, os governadores dos bancos centrais dos países da área do euro (doze, atualmente).
Essa composição tem levantado alguns reparos, pelo fato de apenas seis dos seus membros serem nomeados em nível central e verem a sua ação sujeita ao acompanhamento/ fiscalização por parte do PE, sendo doze os representantes dos bancos centrais nacionais. Como termo de comparação, invoca-se o Fed norte-americano, em que sete membros são nomeados em nível central e apenas cinco representam os bancos centrais dos estados federados.

No Conselho, as decisões são tomadas por maioria simples, cabendo um voto a cada membro. Nas questões importantes, no entanto, pode exigir-se maioria qualificada, considerando-se validamente tomadas as deliberações aprovadas por um número de votos que representem $2 / 3$ do capital subscrito do BCE e provenham de pelo menos metade dos acionistas (art. 10 do Protocolo).

No exercício das suas funções, os membros do Conselho do BCE não atuam como representantes dos seus países de origem nem sequer como representantes dos BCN a cuja direção presidem, intervindo a título pessoal, sem qualquer vínculo de dependência, princípio que justifica a solução de uma pessoa, um voto. Mas os críticos da solução consagrada para a composição do Conselho do BCE temem que desta composição possa resultar uma prática de votação inspirada pelos interesses nacionais dos doze representantes dos $\mathrm{BCN}$, que poderão fazer acordos para obter maiorias (desrespeitando a natureza de órgão colegial do Conselho do BCE). Em resolução do PE (A4-0030/1999) refere-se o "duplo risco de que o Conselho de Governadores se transforme numa câmara de representantes nacionais e de que o BCE se veja reduzido a 
um simples secretariado do SEBC'. Daí as propostas do PE (até agora recusadas pelo BCE) no sentido de assegurar maior transparência do processo de tomada de decisões no nível do Conselho do BCE, mediante a publicação das atas (sumárias ou de pormenor) e do registo das votações.

As competências principais do Conselho são as que seguem:

a) adoção das Orientações e Decisões necessárias ao desempenho das atribuições cometidas ao Eurossistema pelo Tratado e pelos Estatutos;

b) definição da política monetária na área do euro, incluindo os objetivos monetários intermédios, principais taxas de juro e aprovisionamento de reservas no Eurossistema, tomando as Decisões e adoptando as Orientações necessárias à respectiva execução;

c) decisão sobre a utilização de outros métodos operacionais de controle monetário;

d) adopção do Regulamento relativo ao cálculo e determinação das reservas mínimas de caixa;

e) adoção de Regulamentos para assegurar a eficiência e o bom funcionamento dos sistemas de pagamento e de compensação na Comunidade;

f) emissão de Orientações relativas às operações dos bancos centrais nacionais e dos Estados-Membros com os ativos de reserva remanescentes;

g) tomada de medidas necessárias para assegurar o cumprimento das Orientações e Instruções do BCE e a definição das informações que devem ser fornecidas pelos bancos centrais nacionais; h) cumprimento das funções consultivas do BCE;

i) adoção das Regras de Procedimento que determinam a organização interna do BCE e dos seus órgãos de decisão;

j) autorização da emissão de notas de banco em euros e do limite de emissão das moedas de euros na área do euro;

k) fixação das regras necessárias para a uniformização dos processos contabilísticos e das declarações das operações efetuadas pelos bancos centrais nacionais.

A Comissão Executiva é constituída por seis membros (Presidente, Vice-Presidente e quatro Vogais), nomeados por comum acordo dos Estados-membros da CE, dentre personalidades de reconhecida competência, para um mandato de oito anos (não renovável), durante o qual não têm que prestar contas a qualquer instância política democraticamente legitimada. Essa Comissão assegura a gestão das atividades correntes do BCE, decidindo por maioria simples, tendo cada membro um voto, e o Presidente, voto de qualidade.

Cabe à Comissão Executiva:

a) a execução da política monetária, em conformidade com as Orientações e Decisões do Conselho do BCE;

b) a emissão das Instruções necessárias para que os bancos centrais nacionais apliquem as Orientações e Decisões do Conselho;

c) a gestão das atividades correntes do BCE;

d) o exercício de todos os poderes nela delegados pelo Conselho, incluindo os poderes de natureza regulamentar.

Justifica-se uma chamada de atenção para os contornos excepcionais do processo de nomeação dos membros da Comissão 
Executiva. As nomeações são feitas de comum acordo pelos Chefes de Estado e de Governo dos Estados-Membros, sob recomendação do Conselho Europeu e após este ter consultado o Parlamento Europeu (PE) e o Conselho do BCE. Todo esse aparato terá visado 'legitimar' este órgão do BCE, que toma decisões políticas do mais alto relevo para milhões de pessoas sem qualquer responsabilização política. Mas daqui poderá resultar o efeito perverso de fortalecer e consolidar o poder da Comissão Executiva, alargando a sua esfera de ação como órgão todo-poderoso do BCE, vocacionado para assumir todas as enormes competências do Banco.

Enquanto as Instituições da Comunidade (Parlamento Europeu, Conselho, Comissão, Tribunal de Justiça e Tribunal de Contas) são tratadas em conjunto, determinando o art. 7..$^{\circ}$ TCE que cada uma delas atue nos limites das atribuições e competências que lhe são conferidas pelo Tratado, o SEBC e o BCE são tratados à parte, no art. $8 .^{\circ}$. Em verdade, tanto o SEBC como o BCE gozam de um estatuto de independência perante as instituições ou organismos comunitários e os governos dos Estados-Membros e têm a sua esfera de atividade claramente delimitada nos Estatutos (que são parte integrante do TCE).

$\mathrm{O}$ art. 113 TCE prevê a possibilidade de o Presidente do Conselho Europeu (ou do Conselho ECOFIN) e o Comissário responsável pelos Assuntos Econômicos e Monetários participarem nas reuniões do Conselho do BCE, mas sem direito de voto, reconhecendo àquele o direito de submeter moções à deliberação do Conselho do BCE.
O mesmo artigo prescreve que o Presidente do BCE será convidado a participar nas reuniões do Conselho Europeu sempre que este delibere sobre questões relativas aos objetivos e às atribuições do SEBC.

Esse artigo determina ainda que o BCE deve enviar anualmente ao PE, ao Conselho Europeu e à Comissão um relatório sobre as atividades do SEBC e sobre a política monetária do ano anterior e do ano em curso, relatório que o Presidente do BCE apresentará ao Conselho e ao PE. Com base nesse relatório, $\mathrm{O} P E$ pode proceder a um debate de carácter geral. $\mathrm{O}$ art. 113 prevê também que o Presidente do BCE e outros membros da Comissão Executiva possam, a pedido do $\mathrm{PE}$ ou por sua iniciativa, ser ouvidos pelas Comissões competentes do PE.

Não obstante, no domínio das políticas econômicas, as relações do BCE com outras instâncias (comunitárias ou nacionais) competentes nesse domínio mantêm-se ao nível de um diálogo não vinculativo, do qual não pode decorrer qualquer compromisso do BCE no sentido de vir a coordenar as suas decisões de política monetária com quaisquer outras políticas (foi este o entendimento expresso pelo Conselho de Helsínquia, em dezembro/1999).

É um diálogo muito mais limitado do que aquele que vem sendo defendido há anos pelo PE, no âmbito de um processo de controle democrático do $\mathrm{BCE}$, que deveria passar, nomeadamente, pela realização de reuniões trimestrais (com perguntas e respostas) do PE com o Presidente do BCE e outros membros da Comissão Executiva e pela obrigatoriedade de publicação das atas das reuniões do Conselho do BCE, com indicação das decisões tomadas e respectiva fundamentação. O PE 
recomendou mesmo que, em próxima revisão do TCE, seja reconhecida a possibilidade de o PE votar uma moção de censura ao Presidente do BCE, nos casos extremos de incumprimento dos critérios referidos no art. 105 TCE.

No que toca à sua independência, o estatuto do BCE faz dele o banco central que, em todos os tempos e em todo o mundo, goza de maior independência, não só em relação à escolha dos instrumentos a utilizar, mas também no que respeita à definição dos seus objetivos, à concretização do sentido do art. 105 TCE.

A independência financeira do $\mathrm{BCE}$ constitui um sinal claro da sua independência institucional: o orçamento do BCE não integra o orçamento geral da CE nem o BCE está sujeito à fiscalização do Tribunal de Contas da $\mathrm{CE}$, mas à de um auditor independente.

$\mathrm{O}$ estatuto do BCE acompanha de perto o estatuto do Deutsche Bundesbank antes da entrada da Alemanha para a UEM. Com uma diferença relevante: o estatuto do banco central alemão podia ser alterado pelo Parlamento da Alemanha, mas o estatuto do BCE não pode ser alterado por ação soberana de nenhum governo ou parlamento nacional, tampouco pelo PE.

$\mathrm{O}$ art. 101 TCE consagra a autonomia da política monetária perante a política orçamental na medida em que proíbe ao BCE e aos bancos centrais nacionais dos EstadosMembros a concessão de créditos, sob a forma de descobertos ou sob qualquer outra forma, em benefício de instituições ou organismos da Comunidade, dos governos centrais, autoridades regionais ou locais, de outras autoridades públicas, de organismos ou empresas do setor público dos Estados-
Membros, bem como a compra direta de títulos da dívida pública a essas entidades.

Quanto à competência e à capacidade de manobra do SEBC e do BCE, o art. 105 TCE dispõe que "o objetivo primordial do SEBC é a manutenção da estabilidade dos preços", dele resultando que "as políticas econômicas gerais da Comunidade" só poderão ser apoiadas pelo BCE se esse apoio puder ser dado "sem prejuízo do objetivo da estabilidade dos preços", o qual, proclamado como objetivo primordial, se sobrepõe a todos os outros (cfr. também art. 4. $^{\circ}$ ).

Por sua vez, o art. 108 TCE e o art. 7. do Protocolo acima referido dispõem que o BCE deve agir com inteira independência relativamente aos órgãos do poder político: "O BCE, os bancos centrais nacionais ou qualquer membro dos respectivos órgãos de decisão não podem solicitar ou receber instruções das instituições ou organismos comunitários, dos governos dos EstadosMembros ou de qualquer outra entidade. As instituições e organismos comunitários, bem como os governos dos Estados-Membros, comprometem-se a respeitar este princípio e a não procurar influenciar os membros dos órgãos de decisão do BCE ou dos bancos centrais nacionais no exercício das suas funções".

O BCE é, como se vê, uma instância supranacional, que representa, neste âmbito, uma solução de natureza federal. Apesar de a UE não ser um Estado federal, o BCE é, de fato, em banco centralfederal ("o Eurossistema foi dotado de um núcleo central de soberania”, lê-se no Boletim Mensal do BCE, outubro/ 2000 , p.55), e o euro apresenta-se como o atributo de uma 'soberania comunitária' que (ainda) não existe. 
3. Com a ratificação do TUE pelos vários Estados-Membros, a problemática da independência (e das competências efetivas) dos bancos centrais dos países integrantes da CE passou a ter um novo enquadramento.

3.1. Em Portugal, a terceira revisão constitucional (LC n. ${ }^{\circ} 1 / 92$, de 25 de novembro) refletiu isso mesmo, alterando novamente o estatuto constitucional do BP. Segundo o novo texto do art. 105 CRP, "o Banco de Portugal, como banco central nacional, colabora na definição e execução das políticas monetária e financeira e emite moeda, nos termos da lei”.

O banco perdia o monopólio da emissão de moeda e continuava a não ter competência para definir e a não ter o direito de executar as políticas monetária e financeira. Cabia-lhe tão-só colaborar na definição e na execução dessas políticas, ambas as quais competiam ao Governo, como "órgão de condução da política geral do País” (art. 185 CRP).

Mesmo depois da revisão constitucional de 1992 , a LO de 1990 continuava a ir além do texto constitucional, ao reconhecer ao BP competência para executar (e não apenas o direito e o dever de colaborar na execução da) a política monetária. A esse respeito, o legislador constituinte português manifestou sempre, nas revisões constitucionais, uma grande dificuldade em chamar as coisas pelos seus nomes.

Embora o objetivo principal da revisão constitucional de 1992 tivesse sido o de pôr a CRP de acordo com o TUE, de modo a abrir caminho à ratificação do Tratado, a verdade é que o regime consagrado na nova redação do art. $105 \mathrm{CRP}$ dificilmente poderia ser considerada compatível com os compromissos assumidos no Tratado de Maastricht. Bastaria recordar que do texto desse preceito constitucional não resultava que a competência para decidir da emissão de moeda deixara de pertencer ao BP para passar a caber ao BCE, podendo os bancos centrais nacionais encarregar-se da execução das decisões do BCE, mas apenas no quadro dessas mesmas decisões. $\mathrm{O}$ referido preceito falava do direito/dever do BP de colaborar na definição e execução das políticas monetária e financeira, mas 'ignorava' que, segundo o TUE, é ao BCE que cabe definir e executar a política monetária única da Comunidade.

Refira-se ainda que o DL n. ${ }^{\circ}$ 289/92, de 31 de dezembro (Regulamento Geral das Instituições de Crédito e Sociedades Financeiras - RGICSF), promulgado depois da revisão constitucional de 1992, continuou a consagrar soluções que ilustravam um grau considerável de subordinação do BP ao Governo.

O art. 91 atribuía ao Ministro das Finanças a superintendência dos mercados monetário, financeiro e cambial, designadamente a coordenação da atividade dos agentes do mercado com a política econômica e social do Governo.

Ao Governo - por meio de portaria conjunta do Primeiro Ministro e do Ministro das Finanças, ouvido o BP - cabia também a competência para ordenar as medidas apropriadas (nomeadamente a suspensão temporária de determinados mercados ou de certas categorias de operações ou o encerramento temporário de instituições de crédito) a situações de perturbação dos mercados monetário, financeiro ou cambial que pusessem em grave perigo a economia nacional. 
Como índices da subordinação do BP ao Governo, ressaltavam ainda - para além do processo de nomeação do Governador e dos membros do Conselho de Administração - o fato de o Banco ser obrigado (arts. 62 e 64 da LO) a comunicar o seu orçamento anual ao Ministro das Finanças até 30 de novembro do ano anterior, e o fato de o Banco ser obrigado a submeter à aprovação do Ministro das Finanças, até 31 de março de cada ano, o relatório, o balanço e as contas de gerência do ano anterior (exigências que se mantêm, sem significado relevante, na LO aprovada pela Lei n. ${ }^{\circ}$ 5/98).

3.2. Na seqüência do Tratado de Maastricht e da revisão constitucional de 1992, o DL n. ${ }^{\circ} 231 / 95$, de 12 de setembro, veio introduzir no ordenamento jurídico português o regime resultante do art. 101 TCE, alterando, em conseqüência, algumas normas importantes da LO do Banco de Portugal, no sentido de lhe reconhecer, claramente, um maior grau de autonomia.

O mais claro sinal disso é o regime resultante da nova redação do art. 25 LO, nos termos da qual ficava vedado ao BP:

a) conceder crédito, sob qualquer forma, ao Estado português e serviços ou organismos dele dependentes, bem como a outras pessoas coletivas de direito público e a empresas públicas ou quaisquer entidades sobre as quais o Estado português, as Regiões Autônomas ou as autarquias locais possam exercer, direta ou indiretamente, influência dominante;

b) garantir quaisquer obrigações do Estado ou das demais entidades acabadas de referir; c) comprar diretamente títulos de dívida emitidos pelo Estado ou pelas demais entidades atrás referidas.

Isso significa que, doravante, somente no mercado secundário e no quadro das operações de open market, o BP poderia adquirir títulos da dívida pública. E talvez devesse entender-se que só o podia fazer quando essa operação de compra se justificasse no âmbito da prossecução dos objetivos de controle monetário que competiam ao Banco (os estatutos do Deutshche Bundesbank impunham-lhe expressamente essa limitação). Excepcionalmente (e transitoriamente), apenas as Regiões Autônomas dos Açores e da Madeira mantinham a facilidade de se beneficiarem de uma conta gratuita aberta no Banco (Protocolo 8 anexo ao TUE e art. 2. ${ }^{\circ} \mathrm{DL} \mathrm{n} .^{\circ} 231 / 95$, de 12 de setembro).

$\mathrm{O}$ art. 3. ${ }^{\circ} \mathrm{LO}$ passou a dispor que o BP é o Banco Central da República Portuguesa, o qual "tem como atribuição principal manter a estabilidade dos preços, tendo em conta a política económica global do Governo".

Por outro lado, o art. 18 LO atribuía ao BP “a condução da política monetária” e o direito/dever de "colaborar na definição e executar a política cambial" e de "aconselhar o Governo nos domínios monetário, financeiro e cambial".

Confrontando com a norma do art. 105 CRP (texto da LC n. ${ }^{\circ} 1 / 92$ ), pode-se concluir que o tex to da LO do BP (na redação de 1995) veio retirar ao banco central português a competência, reconhecida na CRP, para colaborar na definição da política financeira, reconhecendo-lhe apenas capacidade para aconselhar o Governo nesse domínio. Em contrapartida, no campo da política monetária, 
em vez de se limitar a reconhecer-lhe competência para colaborar na definição $e$ execução da política monetária (art. 105 CRP), veio atribuir-lhe a competência para conduzir a política monetária (ficando a dúvida sobre se a condução abrange a definição e a execução ou somente a execução), e impôs a manutenção da estabilidade dos preços como atribuição principal da sua ação (sendo certo que, mesmo após a revisão de 1992, a CRP não inclui a estabilidade dos preços entre os objetivos da política econômica).

A LO (versão 1995) aproximou-se, sem dúvida, das concepções monetaristas consagradas em Maastricht, mas não respeitou o normativo constitucional.

Saliente-se, porém, que o texto de 1995 continuava a impor ao BP o dever de, na prossecução da sua atribuição principal de manutenção da estabilidade dos preços, ter em conta a política econômica global do Governo. Mantinha-se, pois, sensivelmente, o regime previsto no art. 92 do RGICSF, segundo o qual o BP, no exercício da sua competência de orientação e fiscalização dos mercados monetário e financeiro, devia ter em conta a política econômica e social do Governo.

A essa luz, dir-se-ia que o BP, apesar da acrescida autonomia que lhe era reconhecida perante o Governo, não poderia desenvolver a sua atividade de costas voltadas para a realidade econômica e social do País, inteiramente à margem dos objetivos de política econômica e social definidos pelo Governo, como órgão responsável pela “condução da política geral do País”. Como instância autônoma do Governo, o BP não poderia (e, muito menos, deveria) sacrificar à manutenção da estabilidade dos preços a prossecução de outros objetivos de política definidos pelo Governo (o crescimento econômico, o combate ao desemprego e a promoção do emprego, v.g.). No entanto, o legislador de 1995 sabia que Portugal já tinha ratificado o Tratado de Maastricht e que, nos termos do TUE e da nova redação do art. 105 CRP, o objetivo da manutenção da estabilidade dos preços se sobrepunha a quaisquer outros objetivos de política econômica definidos pelo Governo. É, mais uma vez, o estranho comportamento do legislador de não querer aceitar a realidade, como que receoso de que o acusem de ter provocado ou aceito soluções inaceitáveis.

3.3. Perfeitamente consciente da profundidade das alterações introduzidas pela entrada em funcionamento da UEM, o art. 109 TCE prescreve que "cada um dos Estados-Membros assegurará, o mais tardar até a data da instituição do SEBC, a compatibilidade da respectiva legislação, incluindo os estatutos do seu banco central nacional, com o presente Tratado e os Estatutos do SEBC" (cfr. também o art. 14 dos Estatutos do SEBC).

Em Portugal, a revisão constitucional de 1997 (LC n. ${ }^{\circ}$ 1/97, de 20 de setembro) e a Lei n. ${ }^{\circ}$ 5/98, de 31 de janeiro, vieram, em consonância com o citado art. 109, introduzir alterações no estatuto constitucional e na Lei Orgânica do Banco de Portugal.

Depois da revisão de 1997, o art. 102 CRP, em vez de determinar (como o anterior art. 105) que o BP "colabora na definição e execução das políticas monetária e financeira e emite moeda, nos termos da lei", proclama 
que o BP "exerce as suas funções nos termos da lei e das normas internacionais a que o Estado português se vincula".

Com esta 'norma vazia', o legislador constituinte continua a ter 'vergonha' de reconhecer a verdade, ao não afirmar expressamente a independência do BP, embora ela seja um elemento integrante do estatuto do banco central português, porque decorre de normas internacionais a que Portugal se vinculou (o TUE).

O TCE passa a ser, também a esse respeito, como já se sabia, a verdadeira Constituição Econômica de Portugal.

A nova LO do Banco de Portugal (aprovada pela Lei n. ${ }^{\circ}$ 5/98, de 31 de janeiro, para entrar em vigor no dia $1 .^{\circ}$ de janeiro de 1999, já parcialmente alterada pelo DL $n{ }^{\circ}$ 118/2001, de 17 de abril) anula claramente a existência autônoma do BP como banco central da República Portuguesa, embora continue a considerá-lo como tal.

Com efeito, $\mathrm{o}$ art. $3 .^{\circ} \mathrm{vem}$ tornar claro que o BP faz parte integrante do SEBC. O BP passa, pois, a ser uma espécie de 'repartição' periférica do SEBC. Revelador dessa situação é o fato de os próprios Estatutos do BCE assumirem competências no que tange ao mandato dos governadores dos bancos centrais nacionais, apesar de estes serem pessoas jurídicas diferentes do BCE. Por imposição do art. 14.2. daqueles Estatutos, esse mandato não deve ser inferior a cinco anos, e o Governador somente pode ser demitido das suas funções se deixar de preencher os requisitos necessários ao exercício das mesmas ou se tiver cometido falta grave.

As funções de banco central passam a caber ao SEBC e ao BCE, uma vez que, nos países que adotaram o euro como moeda, são transferidas da esfera da soberania nacional para a de competências do SEBC/BCE como instâncias comunitárias supranacionais.

$\mathrm{O}$ n. 2 do art. 3..$^{\circ}$ da nova LO dispõe que o BP prossegue os objetivos e participa no desempenho das atribuições cometidas ao SEBC. Ou seja: o BP deixa de ter atribuições e objetivos próprios, autonomamente determinados no âmbito da soberania portuguesa; ao invés, fica sujeito ao disposto nos estatutos do SEBC/BCE, devendo atuar em conformidade com as orientações e instruções que o BCE lhe dirigir, ao abrigo dos seus Estatutos.

4. A enumeração que será feita a seguir das tarefas que continuam a caber ao BP após o início da $3 .^{a}$ fase do processo de concretização da UEM (1. ${ }^{\circ}$ de janeiro de 1999) ajudará a perceber melhor qual o seu papel atual como "banco central nacional".

4.1. Na qualidade de banco central, o BP está autorizado a realizar as seguintes operações bancárias:

a) redescontar e descontar letras, livranças, extratos de fatura, warrants e outros títulos de crédito de natureza análoga;

b) aceitar, do Estado, depósitos à vista, bem como aceitar depósitos, à vista ou a prazo, das instituições de crédito, sociedades financeiras e outras instituições financeiras;

c) conceder empréstimos ou abrir crédito em conta corrente, nas modalidades que considerar aconselháveis, desde que as operações sejam devidamente caucionadas, às instituições de crédito e às sociedades financeiras; 
d) comprar e vender títulos de dívida pública em mercado secundário, com as limitações já vistas (art. 18 LO/1998).

Mas o art. 24 desta LO torna explícito aquilo que sempre decorreria do TCE: todas as operações que o BP fica autorizado a desenvolver devem ser realizadas "a fim de alcançar os objectivos e de desempenhar as atribuições do SEBC'. Mais uma vez resulta claro o papel instrumental do BP relativamente ao SEBC/BCE, a cujas orientações e instruções fica subordinado, também nesse domínio.

4.2. Na qualidade de banco central, continua a pertencer ao BP a competência para "gerir as disponibilidades externas do País ou outras que lhe estejam cometidas", para "agir como intermediário nas relações monetárias internacionais do Estado" e para "aconselhar o Governo nos domínios econômico e financeiro, no âmbito das suas atribuições". Porém todas essas competências devem ser exercidas "sem prejuízo dos condicionalismos decorrentes da sua participação no SEBC”, (art. 12 LO), i. é, sem prejuízo do dever do BP de atuar sempre em conformidade com as orientações e instruções que o BCE lhe dirigir, e tendo sempre em vista os objetivos da atuação do SEBC/BCE como Banco Central da Comunidade Européia.

4.3. O art. 14 LO atribui ao BP competência para regular, fiscalizar e promover o bom funcionamento dos sistemas de pagamento. Mas esse preceito logo acrescenta que essas competências se justificam somente "no âmbito da sua participação no SEBC”.

4.4. $\mathrm{O}$ art. 18 dos Estatutos do SEBC/ $\mathrm{BCE}$ autoriza os bancos centrais nacionais a intervir nos mercados financeiros, quer comprando e vendendo firme (à vista ou a prazo) ou ao abrigo de acordos de recompra, quer emprestando ou tomando de empréstimo ativos e instrumentos negociáveis (denominados em moedas da Comunidade ou não), bem como metais preciosos.

Entretanto, acautela que essas competências são legítimas apenas "a fïm de alcançarem os objetivos e de desempenharem as atribuições do SEBC". E o art. 18.2. acrescenta que “o BCE definirá os princípios gerais para as operações de open market e de crédito a realizar por si próprio ou pelos bancos centrais nacionais".

4.5. Embora tenha praticado, até 1975 , o desconto direto de títulos apresentados para o efeito por particulares e por instituições nãofinanceiras, o Banco de Portugal não efetua, atualmente, transações de natureza financeira com particulares nem com instituições nãofinanceiras. Mas cabe-lhe, como banco central, velar pela estabilidade do sistema financeiro nacional, assegurando, com essa finalidade, a função de refinanciador de última instância (art. 12, al. c) da LO aprovada pela Lei n. ${ }^{\circ}$ 5/98).

4.6. Ao fim e ao cabo, talvez o art. 13 defina a verdadeira função do BP: "a recolha e elaboração das estatísticas monetárias, financeiras, cambiais e da balança de pagamentos, designadamente no âmbito da sua colaboração com o BCE." Quanto ao mais, tudo se resumirá à ação do Governador do BP no exercício das funções de membro do Conselho do BCE (art. 28 LO). A atuação e o voto do Governador do BP no Conselho do BCE podem influenciar as deliberações sobre as políticas e as medidas que são próprias de um banco central. A verdade, 
porém, é que os governadores dos BCN intervêm nos trabalhos do Conselho a título individual, não representando a administração do banco central a que presidem e muito menos o seu país de origem.

4.7. No que tange à função emissora, o BP gozou, até 1992, do estatuto de banco emissor, i.é, do direito exclusivo de emitir notas e de colocar em circulação as moedas metálicas (art. 105 CRP e art. 6. ${ }^{\circ} \mathrm{Ss}$ LO/1990).

Mas o Tratado de Maastricht veio acrescentar ao Tratado de Roma o novo art. 106. Prevendo a entrada em vigor do Tratado, o art. 105 da CRP foi alterado em 1992, passando a determinar que o BP "emite moeda, nos termos da lei”. Após a revisão de 1997, o art. 102 CRP dispõe que o BP "exerce as suas funções nos termos da lei e das normas internacionais a que o Estado português se vincule".

Após a adoção do euro como moeda, o art. 6. ${ }^{\circ}$ da nova LO/1998 limita-se a definir que, "nos termos do art. 106 do Tratado que Institui a Comunidade Européia, o Banco emite notas com curso legal e poder liberatório". Ora, o art. 106, n. 1 TCE atribui ao BCE, a partir de $1 .^{\circ}$ de janeiro de 1999 , o direito exclusivo de autorizar a emissão de notas de banco (euros) nos países que integram a UEM, sendo estas (que tanto podem ser emitidas pelo BCE como pelos bancos centrais nacionais) as únicas com curso legal nesses países.

Relativamente às moedas metálicas, o art. 106, n. 2 TCE reconhece aos EstadosMembros o poder de emitir moedas metálicas, contudo reserva para o BCE a competência para aprovar o volume da respectiva emissão. Em conformidade, a nova LO do BP estipula agora que o Banco põe em circulação as moedas metálicas, incluindo as comemorativas (art. 6..$^{\circ}$ n. ${ }^{\circ} 2$ da Lei n..$^{\circ}$ 5/98). Ou seja: o Estado manda cunhar as moedas na Casa da Moeda, mas elas somente são postas em circulação por intermédio e sob requisição do Banco (art. 6. ${ }^{\circ}$ n. $\left.^{\circ} 3 \mathrm{LO}\right)$, isto é, à medida que o BP vai fazendo pagamentos com elas ou as troca por outras. Entretanto, não cabe ao BP nem ao Estado português decidir do montante da emissão, mesmo tratando-se de moedas comemorativas.

4.8. Não é uniforme o regime dos bancos centrais como banqueiros do Estado. Por vezes, o banco central só pode financiar o Tesouro concedendo-lhe adiantamentos temporários que se destinam a antecipar a cobrança de impostos; outras vezes, pode conceder empréstimos ao Estado até certo montante e até certo prazo; em alguns casos, prevê-se a possibilidade de concessão de empréstimos extraordinários em situações graves de guerra ou de acentuada depressão econômica, v.g.

Em Portugal, o regime regulador das relações entre o Estado e o BP como banqueiro do Estado sofreu a evolução aqui descrita. Em nome da independência do Banco, a LO/1995 (arts. 25 e 26) veio proibir que ele concedesse crédito ao Estado, sob qualquer forma, o que significava que só no mercado aberto o Banco poderia adquirir títulos da dívida pública.

A nova LO (que entrou em vigor em 1. de janeiro de 1999) consagra um regime idêntico ao que atrás fica descrito, que é, aliás, o que resulta do TUE (arts. 18 e 19 da LO aprovada pela Lei n. ${ }^{\circ}$ 5/98): ao BP é vedado conceder descobertos ou qualquer 
outra forma de crédito ao Estado e serviços ou organismos dele dependentes a outras pessoas coletivas de direito público e a empresas públicas ou quaisquer entidades sobre as quais o Estado, as Regiões Autônomas ou as Autarquias Locais possam exercer, direta ou indiretamente, influência dominante; ao BP é também vedado garantir quaisquer obrigações do Estado ou das outras entidades acabadas de referir, bem como a compra direta de títulos de dívida emitidos pelo Estado ou por quaisquer daquelas entidades.

Fica assim garantida a separação entre a política monetária e a política orçamental, impedindo que as políticas públicas sejam financiadas por via monetária.

4.9. As competências do BP como autoridade cambial (nomeadamente a regulamentação do mercado cambial e a intervenção para assegurar a gestão do regime de controle de câmbios) eram já muito limitadas, dadas as restrições decorrentes da adesão do escudo (6 de abril de 1992) ao Mecanismo de Taxas de Câmbio do Sistema Monetário Europeu (banda de flutuação do escudo) e as exigências do processo de liberalização integral dos movimentos de capitais em consonância com as obrigações e as regras prevalecentes no espaço comunitário, processo que ficou concluído em dezembro de 1992 (DL n. ${ }^{\circ}$ 13/90, de 8 de janeiro; DL n. ${ }^{\circ}$ 176/91, de 14 de maio, que transpôs para o direito interno a Diretiva do Conselho n. ${ }^{\circ}$ 88/361/CEE, de 24 de julho de 1988; DL n. ${ }^{\circ}$ 298/92, de 31 de dezembro; DL n..$^{\circ}$ 170/93, de 11 de maio).

A nova LO continua a considerar o Banco de Portugal como "autoridade cambial da República Portuguesa” (art. 20). Trata-se de puro eufemismo, uma vez que, como autoridade cambial, as competências do BP reduzem-se a autorizar e fiscalizar os pagamentos externos que disso careçam, nos termos do TCE, e a definir os princípios reguladores das operações sobre ouro e divisas (art. 21).

Mesmo no que toca à participação do BP no capital de instituições monetárias internacionais e à participação nos respectivos órgãos sociais, o art. 23 LO é claro na reserva de que o BP somente o pode fazer "com o acordo do BCE".

No essencial, o que importa é que o disposto no TCE implica que o BP deixa de poder intervir sobre as taxas de câmbio com o objetivo de obter vantagens para a economia portuguesa nas relações com o exterior. A política cambial deixa de figurar no arsenal de instrumentos de política ao dispor do Estado português.

A política cambial não poderá servir para prosseguir objetivos permanentes de política econômica. Porém, a manipulação da taxa de câmbio pode ser um mecanismo importante para anular ou reduzir choques assimétricos. A sua perda pode significar, para alguns países, um custo elevado da união monetária, por se verem condenados a sofrer crises mais profundas e diferenças mais acentuadas no ciclo relativamente a outras economias integrantes da união monetária.

4.10. Como autoridade monetária, o BP continua a deter a competência para orientar e fiscalizar os mercados monetário e cambial. Mas apenas "no âmbito da sua participação no SEBC" e "de acordo com as normas adoptadas pelo BCE”' (arts. 15 e 16 LO).

Nesse domínio, cabe ao Banco: 
a) Adotar providências genéricas ou intervir, sempre que necessário, para garantir os objetivos da política monetária e cambial, em particular no que se refere ao comportamento das taxas de juro e de câmbio.

b) Receber as reservas de caixa das instituições a elas sujeitas e colaborar na execução de outros métodos operacionais de controle monetário "a que o BCE decida recorrer" (cfr. art. 20 dos Estatutos do SEBC/BCE).

Saliente-se, no entanto, que, nos termos do art. 19.1 dos Estatutos do SEBC/BCE, é ao BCE que cabe o poder de exigir que as instituições de crédito estabelecidas nos Estados-Membros constituam reservas mínimas junto do BCE e dos bancos centrais nacionais, para prossecução dos objetivos de política monetária.

A obrigatoriedade de constituição de reservas mínimas (por meio de contas de reserva junto dos bancos centrais nacionais, porque o BCE entendeu ser esta a solução mais adequada) resulta hoje, efetivamente, de um Regulamento do BCE: o Regulamento (CE) n. ${ }^{\circ}$ 2818/98, de $1 .^{\circ}$ de dezembro de 1998 , aprovado tendo em conta o Regulamento (CE) do Conselho, de 23 de novembro de 1998.

c) Estabelecer os condicionalismos a que devem estar sujeitas as disponibilidades e as responsabilidades sobre o exterior que podem ser detidas ou assumidas pelas instituições autorizadas a exercer o comércio de câmbios.

d) Na qualidade de autoridade monetária, parece que continua a caber ao BP a competência para autorizar a constituição de instituições de crédito e de sociedades financeiras (arts. 16 e 175 DL n. ${ }^{\circ}$ 298/92), bem como para intervir na administração de instituições em situação difícil, determinar medidas de saneamento e de recuperação financeira e revogar a autorização para o exercício da atividade (arts. 139 a 153 e 198 DL n. ${ }^{\circ}$ 298/92). O exercício dessa competência não pode, porém, pôr em causa o chamado princípio do passaporte comunitário, que teve acolhimento do DL n. ${ }^{\circ} 298 / 92$ (arts. 44 ss e 60 ss).

e) Como autoridade monetária, cabe também ao BP exercer a supervisão das instituições de crédito, sociedades financeiras e outras entidades a ela sujeitas (nomeadamente as empresas de investimento), estabelecendo diretivas para a sua atuação e para assegurar os serviços de centralização de riscos de crédito (art. 17 LO/1998 e arts. 93, 116 e 197 DL n. ${ }^{298 / 92) . ~}$

Dentre os poderes de supervisão do BP merecem referência especial os poderes de supervisão prudencial, destinados a assegurar que as instituições financeiras apliquem os fundos de que dispõem de modo a oferecer a todo o tempo níveis adequados de liquidez e de solvabilidade (arts. 94 e 197 DL n. ${ }^{\circ}$ 298/92). Esse diploma veio dar particular realce às normas prudenciais que se destinam a assegurar a idoneidade, experiência, independência e disponibilidade dos membros dos órgãos de administração das instituições de crédito (arts. 30 a 33) e a idoneidade dos detentores de participações qualificadas em quaisquer instituições financeiras (arts. 102, 103 e 176).

Compete ao BP definir, por Aviso, as relações prudenciais que as instituições sujeitas à sua supervisão devem respeitar, nomeadamente a relação entre os fundos próprios e os ativos e elementos extrapatrimoniais ponderados por coeficientes de 
risco, bem como os limites à concentração de riscos (art. 99 RGICSF). Mas essa competência deve exercer-se no quadro definido pela Diretiva n. ${ }^{\circ}$ 98/31/CE, do Parlamento Europeu e do Conselho, de 22 de junho (que veio alterar a Diretiva n. ${ }^{\circ}$ 93/6/CEE, de 15 de março), a qual foi transposta para o ordenamento jurídico interno português pelo DL n. ${ }^{\circ} 333 / 2001$, de 24 de dezembro.

O BP exerce essa competência sem prejuízo do disposto nos arts. 122 e 198 DL n. 298/92: as instituições de crédito e as sociedades financeiras autorizadas em outros Estados-Membros da CE e que exerçam atividade em Portugal não estão sujeitas à supervisão prudencial do BP, desde que sujeitas à supervisão das autoridades do país de origem.

No que respeita à supervisão prudencial, importa ter em conta o disposto no art. 105, n. 6 TCE e no art. 25 dos Estatutos do SEBC/BCE. Segundo o art. 25.1 destes Estatutos, "o BCE pode dar parecer e ser consultado pelo Conselho, pela Comissão e pelas autoridades competentes dos Estados-Membros sobre o âmbito e aplicação da legislação comunitária relativa à supervisão prudencial e à estabilidade do sistema financeiro".

Nos termos do art. 25.2, o Conselho Europeu, se deliberar por unanimidade e observando as demais condições referidas no art. 105, n. ${ }^{\circ} 6$ do Tratado, pode conferir ao $B C E$ atribuições específicas no que diz respeito às políticas relativas à supervisão prudencial das instituições de crédito e de outras instituições financeiras (excetuando as seguradoras).
A esse propósito, convém sublinhar que de vários lados vem sendo agitada a idéia de uma entidade única encarregada da supervisão na área do euro e que em documento do BCE já foi sugerida a conveniência de integrar em um só organismo as funções de supervisão da banca, dos seguros e do mercado de valores mobiliários (cfr. Nota de 22 de março de 2001 sobre "o papel dos bancos centrais na supervisão prudencial").

5. Em síntese, um dos objetivos definidos em Maastricht (art. 4. ${ }^{\circ}$ TCE) foi a instituição da União Econômica e Monetária, com a criação de uma moeda única e a definição e condução de uma política monetária e de uma política cambial únicas.

$\mathrm{O}$ n. ${ }^{\circ} 2$ do art. 105 TCE determina, em conformidade, que compete ao SEBC "a definição e execução da política monetária da Comunidade".

E o art. 111 define que caberão ao Conselho Europeu as decisões mais importantes no que toca à política cambial da Comunidade, sendo certo que os compromissos assumidos pelo Conselho vinculam não somente as Instituições da Comunidade e o BCE, mas também os Estados-Membros (e, obviamente, os bancos centrais nacionais).

O modelo consagrado no TCE torna os bancos centrais nacionais independentes dos órgãos do poder político, mas retira-lhes toda a competência (e toda a independência) na definição das políticas monetária e cambial nacionais.

A partir do dia 1. ${ }^{\circ}$ de janeiro de 1999 , data em que o euro passou a ser a moeda oficial de Portugal, a LO aprovada pela Lei n. ${ }^{\circ}$ 5/98 significa uma alteração substancial do estatuto do Banco de Portugal. 
Deixou de lhe caber a condução da política monetária, uma vez que, de acordo com a nova redação do art. 105 TCE, é ao SEBC que cabe a definição e a execução da política monetária da Comunidade.

$\mathrm{O} \mathrm{BP}$ ficou reduzido à condição de mera parte integrante do SEBC, ao serviço dos objetivos do SEBC. Este tem como objetivo nuclear a estabilidade dos preços, o qual se sobrepõe a quaisquer outros objetivos de política, uma vez que, de acordo com o TCE, o SEBC somente poderá apoiar as políticas econômicas gerais da Comunidade (ao serviço dos objetivos gerais da Comunidade, definidos no art. $2^{\circ}$ ) se não houver prejuízo do objetivo da estabilidade dos preços.

Ao definir a sua conduta, o BP não poderá ter em conta a política econômica global do Governo português, antes deverá obedecer às orientações e instruções do BCE, o qual, por sua vez, só pode ter em conta as políticas econômicas globais da Comunidade (que podem não coincidir com as políticas adequadas à situação de qualquer um dos Estados-Membros) e apenas na medida em que aquelas políticas não ponham em causa o objetivo da estabilidade dos preços.

Em termos gerais, todas as competências que a LO aprovada pela Lei n. ${ }^{\circ}$ 5/98 atribui ao BP serão exercidas no âmbito da participação deste no $S E B C$, no pressuposto de que o BP é apenas uma parte integrante do SEBC, devendo atuar de acordo com as normas adotadas pelo BCE (ao qual deve colaboração), respeitando os condicionalismos decorrentes da sua participação no $S E B C$ e as orientações e instruções do BCE (cfr. arts. 3. ${ }^{\circ}, 12,13,14$ e 15).

Nesse contexto, pouco significado tem o disposto no n. 4 do art. 54 da LO do Banco
(Lei n. ${ }^{0}$ 5/98), nos termos do qual o Governador do BP informará a AR, por intermédio da Comissão Permanente de Economia, Finanças e Plano, sobre a situação e as orientações relativas à política monetária e cambial, na seqüência da apresentação ao Ministro das Finanças, para aprovação, do relatório do Banco, balanço e contas anuais de gerência. Isso porque nem o Governo nem a $\mathrm{AR}$ podem ter qualquer interferência na ação do BP, obrigado a acatar as orientações e instruções do BCE.

O que conta, a esse propósito, é a competência do BCE para dar orientações e instruções aos bancos centrais nacionais e para tomar as medidas adequadas para assegurar o cumprimento dessas orientações e instruções, incluindo o poder de exigir que lhe seja prestada pelos bancos centrais nacionais toda a informação necessária (art. 14.3 dos Estatutos do SEBC/BCE).

$\mathrm{O}$ art. 54, n. ${ }^{\circ} 6$ da LO esclarece, por outro lado, que o Banco não está sujeito à fiscalização prévia do Tribunal de Contas nem à fiscalização sucessiva, no que diz respeito às matérias relacionadas com a sua participação no desempenho das atribuições cometidas ao SEBC.

5.1. O que fica aqui dito mostra que os governos nacionais - e, em geral, todos os órgãos competentes em matéria de política monetária à escala nacional - estão hoje impedidos de utilizar os instrumentos ao dispor dos bancos centrais para combater a depressão e o desemprego, por mais grave que seja a situação econômica e social. Ao $\mathrm{BCE}$ e aos bancos centrais nacionais é vedado, por outro lado, qualquer compromisso entre a estabilidade dos preços e os outros 
objetivos da política econômica, devendo todos eles ser sacrificados à salvaguarda da estabilidade monetária.

À escala de cada Estado-Membro da CE, a possibilidade de definir e executar a política monetária e cambial deixa de integrar a soberania nacional, sendo irrelevante, nesse nível, o maior ou menor grau de autonomia ou de dependência dos BCN relativamente aos respectivos governos. $\mathrm{O}$ n. 3 do art. 14 dos Estatutos do SEBC determina expressamente que "os bancos centrais nacionais constituem parte integrante do SEBC, devendo atuar em conformidade com as orientações e instruções do BCE'. Do ponto de vista jurídico, é um estranho poder este de uma entidade impor orientações e instruções a pessoas jurídicas diferentes dela.

A adoção da moeda única significa que os países da CE que deixaram de ter moeda própria estão impossibilitados de recorrer, autonomamente (soberanamente), à política monetária e à política cambial como instrumentos de política econômica (estímulo ao crescimento, combate ao desemprego e promoção do pleno emprego, controle da inflação).

O sistema consagrado no TCE, inspirado em uma perspectiva monetarista, claramente 'fundamentalista', acerca da estabilidade monetária, configura, a nosso ver, uma solução qualitativamente (muito) diferente daquela que consideramos razoável (conveniente) para a questão da autonomia aos bancos centrais. Esta deve entender-se como uma independência "dentro de governo", com o conteúdo estritamente necessário para permitir que a política monetária se autonomize da política orçamental, impedindo que os governos tenham acesso privilegiado ou automático ao financiamento junto dos bancos centrais e possam dispor dos instrumentos da política monetária como instrumentos integrantes da caixa de ferramentas ao seu inteiro dispor com vistas nas ações de política conjuntural, nomeadamente para financiar os déficits orçamentais a baixo custo (com juros 'políticos'), tornando possível o aumento irracional e descontrolado das despesas públicas.

5.2. Nos termos do art. 104 TCE e do acordado no Pacto de Estabilidade e Crescimento (PEC) (Resolução do Conselho Europeu de Amsterdã, n. ${ }^{\circ}$ 97/C236/01, de 17 de junho, e dois regulamentos do Conselho: Regulamento CE n. ${ }^{\circ}$ 1466/97 e Regulamento CE n. ${ }^{\circ}$ 1467/97, ambos de 7 de julho), os Estados que integram a UEM estão sujeitos a critérios rígidos limitadores da sua soberania. Trata-se de critérios de orientação monetarista, definidos nas circunstâncias particulares verificadas em 1990, dificilmente justificáveis no plano científico (regressam aos tempos anteriores a Keynes, infligindo pesados custos macroeconômicos, especialmente em tempos de crise), a não ser com base na idéia de que uma política orçamental demasiado expansionista levada a cabo por um dos países da zona euro poderia afetar negativamente os restantes países da zona.

Em primeiro lugar, no que toca à estabilidade dos preços, que o Conselho Geral do BCE definiu, no início de outubro de 1998, como objetivo que se projeta a médio prazo e que deve ser mantido a médio prazo, como "um aumento homólogo do Índice Harmonizado de Preços no Consumidor para a área do euro inferior a $2 \%$ ". 
Em segundo lugar, estão sujeitos a critérios rígidos quanto à relação entre o déficit orçamental e o PIB a preços de mercado (máximo de $3 \%$ ) e àquela entre a dívida pública e o PIB a preços de mercado (máximo de 60\%).

Em outros termos: os países aderentes ao euro deixaram também de poder contar com uma política financeira definida soberanamente e em conformidade com as exigências das flutuações cíclicas da economia.

5.3. Também a política orçamental fica praticamente excluída da soberania nacional. O próprio conteúdo do orçamento das despesas (ou seja, as prioridades políticas que nele se refletem) é em larga medida condicionado pelas decisões das instâncias comunitárias, ao definirem, por um lado, as prioridades das políticas comunitárias (que podem não coincidir com as de cada um dos Estados-Membros, especialmente as de um pequeno país periférico, atrasado e desigual como é Portugal) e, por outro lado, os critérios de elegibilidade dos projetos financiáveis pelos fundos comunitários.

Acresce que, enquanto houver fundos comunitários, cada país que queira se beneficiar deles tem de contribuir com a sua parte do financiamento dos projetos elegíveis, o que implica a afetação de verbas inscritas no OE. Se a essas verbas acrescentarmos aquelas destinadas a cobrir as despesas praticamente incompressíveis (uma percentagem significativa da despesa pública), pouco dinheiro resta para financiar opções autônomas de despesa (sobretudo nos países pobres, como Portugal).

5.4. Perante o elenco de políticas comuns constante do art. 3. ${ }^{\circ}$ TCE (política agrícola e de pescas comum; política comercial comum; política comum no domínio dos transportes e do ambiente; regime único de defesa da concorrência no mercado interno, etc.) e num espaço caracterizado pela livre circulação de mercadorias, de serviços, de capitais e de pessoas, esvazia-se em boa medida o significado das políticas setoriais contempladas na CRP (política agrícola, política industrial, política comercial).

5.5. A perda da soberania nesses domínios é agravada pela perda resultante da alienação do setor empresarial do Estado, que retira do Governo qualquer possibilidade de intervenção direta na economia como empresário com presença relevante em setores estratégicos, com fortes efeitos de irradiação em outros sectores da economia.

5.6. Apesar das perdas de soberania provocadas pelo processo de integração européia, a UE não é um Estado federal. Não tem um governo federal. E não tem um orçamento federal, um orçamento com capacidade de redistribuição e de prossecução de objetivos de estabilização da economia. Este teria de representar, no mínimo, $10 \%$ do PIB comunitário (nos EUA, o orçamento federal absorve cerca de $20 \%$ do PIB da União - R. Solow, Público, 14. de setembro 2002), meta muito distante da cifra atual. Com efeito, o orçamento para 2002 ficou por $1,02 \%$ do PNB dos Estados-Membros da CE, sendo esta a percentagem mais baixa da última década. E acresce que mais de $40 \%$ desse orçamento vão para os subsídios da Política Agrícola Comum, de que aproveitam sobretudo as agriculturas ricas do centro e norte da Europa, com destaque para a agricultura francesa. 
Em caso de crise grave num país como Portugal, não se vê que políticas (nacionais ou comunitárias) poderão ser mobilizadas para ultrapassá-la nem onde poderão ir buscar-se os recursos financeiros indispensáveis para combatê-la. O próprio PE (Resolução A4-0030/1999) reconheceu a inexistência, no quadro da CE, de "meios de governo" ou de "uma instituição encarregada de adoptar medidas para fazer frente a uma crise interna ou internacional".

Nos documentos que antecederam a criação da UEM surgiu a proposta de fazer acompanhar a união monetária da centralização do sistema de seguro de desemprego, de forma a reduzir as conseqüências dos choques assimétricos e a evitar tensões sociais que ponham em risco a união monetária. A idéia não foi adiante. Mas hoje são cada vez mais as vozes que consideram inevitável avançar no sentido de um orçamento comunitário que absorva uma percentagem maior do PIB comunitário, com capacidade para permitir aos países e às regiões mais afetados por choques negativos beneficiaremse de transferências automáticas que reduzam os custos sociais da união monetária.

Há dias, em debate televisivo, dois exministros das Finanças de dois partidos diferentes (um no Governo, outro na oposição) reconheciam que, perante as condições resultantes da UEM e do PEC, o Governo português pouco ou nada podia fazer para combater a recessão, sendo certo que as medidas necessárias para cumprir as imposições monetaristas do PEC (nomeadamente quanto ao déficit público) somente contribuem para agravar o processo recessivo em curso e para afastar mais Portugal dos níveis de desenvolvimento econômico e social dos outros países da CE.
5.7. Tendo em conta a baixa qualidade dos nossos empresários, o grande peso da iliteracia da nossa população e o fraco nível de preparação profissional dos nossos trabalhadores, corremos o risco de alguém levar a sério a idéia de que a política de rendimentos (i. é, a política salarial, ou, talvez melhor, a política do "arrocho salarial") e a política social (ou seja, a política de congelamento ou de desmantelamento do débil 'Estado social' realizado em Portugal) são as únicas políticas utilizáveis para salvaguardar a capacidade competitiva da nossa economia.

Tendo em conta a realidade da política monetária única desenvolvida pelo BCE e as severas constrições à política financeira impostas pelo PEC, vão surgindo de vários lados conselhos no sentido de flexibilizar os 'mercados dos fatores' (leia-se mercado do trabalho) e teorias a 'justificar' a necessidade dessa flexibilização para permitir a adaptação do tecido empresarial às flutuações cíclicas e a absorção dos choques assimétricos pelas economias mais vulneráveis.

A política fiscal também somente poderá ajudar se o País optar por não cobrar impostos sobre os rendimentos do capital e/ou agravar os impostos indiretos (nomeadamente o IVA), que geram, em princípio, efeitos de carácter regressivo do ponto de vista social e dificultam a concorrência das empresas portuguesas com empresas que produzem, em outros países da CE, bens idênticos menos tributados que podem ser adquiridos livremente nesses países (com destaque para os produtos turísticos, especialmente no confronto com a Espanha).

A verdade é que Portugal continua a apresentar uma taxa de analfabetismo de $9 \%$ 
(os analfabetos funcionais representarão uma percentagem muito maior), e o PIB por habitante (11.345,5 euros) foi, em 2001, inferior à metade da média da Europa dos Quinze (23.380 euros). O caminho que aqui se enuncia não será, seguramente, um caminho capaz de alterar essa situação, de consolidar um mínimo aceitável de justiça social e, tendo em conta os constrangimentos resultantes do PEC, dificilmente permitirá os investimentos estruturais que o País precisa fazer na educação e na investigação científica, na saúde e na habitação social, caso se queira construir uma dinâmica de desenvolvimento verdadeiro e sustentado.

6. No dia 24 de setembro de 2002 a Comissão Européia propôs o adiamento, de 2004 (data fixada na Cimeira de Sevilha, em junho de 2002) para 2006, do prazo de cumprimento da meta de um déficit orçamental zero por parte dos países sujeitos ao PEC. O Conselho ECOFIN rejeitou essa proposta em 7 de outubro de 2002, apesar de ser quase certo que, além de Portugal, a Alemanha, a França e a Itália não conseguirão cumprir esse objetivo.

O ministro das Finanças alemão já declarou que a Alemanha não conseguiria, em 2002, manter o déficit público abaixo dos $3 \%$ do PIB, situação que não deixa de ser irônica por parte do país que, em 1997, impôs o PEC aos seus parceiros europeus, por entender que eles não seriam suficientemente disciplinados para se comportar 'com juízo'.

A França (com um dos déficits mais elevados de entre os países da zona euro) revelou, porém, a sua disposição de manter, para 2003, um orçamento que não avançasse no sentido de alcançar o déficit zero nem em 2006, 'ignorando' ostensivamente as imposições do PEC e a deliberação do Conselho ECOFIN para que de os países mais longe do objetivo reduzissem anualmente o déficit estrutural (calculado sobre os efeitos das variações conjunturais do ciclo econômico) em $0,5 \%$ do PIB, bem como as críticas da Comissão Européia e de alguns dos seus parceiros na UE (que chegaram a considerar o orçamento francês "uma provocação"). E o ministro das Finanças francês, em clara oposição ao disposto no TUE, afirmou mesmo: "ainda estamos numa Europa em que a política orçamental de um país está sob o seu controle".

Mas a verdade é que de muitos lados se vem assistindo à proclamação, por parte de teóricos e responsáveis políticos, da necessidade de rever o PEC e afastar o dogmatismo das suas regras. Já em 1999 o PE convidava a Comissão e o Conselho a clarificarem o conteúdo do art. 104 TCE, "tendo em conta o papel das despesas de investimento público na avaliação dos déficits públicos dos Estados-Membros”. A necessidade de rever o critério de definição do déficit público tem sido defendida em vários estudos científicos sobre a matéria.

Em entrevista recente a um jornal português (Público, 14 de setembro de 2002), o Prêmio Nobel da Economia Robert Solow defendeu que os países membros da CE deveriam pôr-se de acordo para suspender os critérios monetaristas que vêm do Tratado de Maastricht e que constam do art. 104 TCE e do PEC.

Um comissário europeu considerou alguns dos aspectos do PEC como "medievais". O Presidente da Comissão Européia, Romano 
Prodi, não hesitou em classificar o PEC de "estúpido, como todas as decisões rígidas" (Le Monde, 17 de outubro de 2002), mantendo o epíteto perante o PE e acrescentando que se limitou a dizer em voz alta o que todos "dizem em privado em conversas quotidianas". Numa situação próxima de uma "deflação mundial" - salientou Prodi - aplicar o PEC no seu rigor, obrigando os países não cumpridores dos seus critérios a respeitar objetivos apertados de redução do déficit "poderia minar as perspectivas econômicas não só dos países em causa, mas de toda a Europa". Alguns comentadores arriscam afirmar que um Prodi tão pouco dado a vôos arriscados não teria ido tão longe se não contasse com o beneplácito franco-alemão. $\mathrm{Na}$ sessão referida do $\mathrm{PE}$, um deputado defendeu a necessidade de um novo pacto de estabilidade, que seja capaz de combinar convergência econômica e convergência social e que inclua o emprego como um dos critérios (cfr. Público, 22 de outubro de 2002).

7. Em outro plano, de muitos lados vem sendo salientado o déficit democrático que, também nesse domínio, vem caracterizando o processo de integração européia.

7.1. O PE defendeu já (Resolução A40030/1999) que "a criação de uma autoridade monetária comum sem verdadeira autoridade política correspondente coloca no centro do debate a questão do nível muito insuficiente da legitimidade democrática alcançada na construção da Europa”.

E tem insistido na necessidade de reforçar as estruturas democráticas de funcionamento da $\mathrm{CE}$, nomeadamente a necessidade de regular a responsabilidade do $B C E$. $\mathrm{Na}$ perspectiva do $\mathrm{PE}$, a organização de um sistema de controle democrático da política monetária é um dos aspectos mais importantes da reforma institucional da $\mathrm{CE}$, no sentido de conciliar a independência do BCE com a responsabilidade democrática, com base no princípio segundo o qual os poderes do BCE não lhe pertencem, antes resultam de delegação operada pelo TUE, e na idéia de que a noção de independência só faz sentido em determinado quadro institucional e democrático.

Em Relatório de 25 de janeiro de 1999 da Comissão de Assuntos Institucionais do PE, de que foi relator o deputado português José Barros Moura, considera-se inaceitável que haja setores da política comunitária cujo controle não caiba aos parlamentos nacionais (após a instituição do SEBC) e não caiba também ao PE, reputando-se insuficiente, a esse respeito, o disposto no art. 113 TCE quanto às relações entre o $\mathrm{BCE}$ e o PE. E recorda-se, a esse propósito, uma proposta de Valéry Giscard d'Estaing de criação de um Comitê Parlamentar do Euro (constituído por 60 deputados europeus dos países da UEM e 60 deputados aos parlamentos nacionais desses mesmos países), perante o qual a direção do BCE deveria apresentar regularmente as orientações de política monetária.

O controle democrático da atuação do $B C E$ é considerado por alguns autores uma condição indispensável ao exercício da sua própria independência, o qual postula a adesão da opinião pública às opções por ele tomadas.

7.2. Partindo da idéia de que "uma união monetária deve ser, antes de mais, um espaço de solidariedade", pretende-se que 
a responsabilidade nestas matérias seja diretamente assumida pelo Conselho Europeu, que tem mais peso, no diálogo com o $\mathrm{BCE}$, que o Conselho ECOFIN.

Esse diálogo só faz sentido - defende-se no referido Relatório Barros Moura - se o art. 103 TCE for lido à luz do disposto no art. 4. ${ }^{\circ}$ (que aponta para a adoção de uma política econômica baseada na estreita coordenação das políticas econômicas dos EstadosMembros) e nos arts. 98 e 99 (segundo os quais os Estados-Membros conduzirão as suas políticas no sentido de contribuir para a realização dos objetivos da Comunidade, considerando as suas políticas econômicas uma questão de interesse comum e coordenando-as no Conselho), bem como no Título VIII TCE referente ao Emprego, incluído na seqüência do Tratado de Amsterdã.

A necessidade de um "diálogo estruturante entre o BCE e o PE" tem sido salientada em vários relatórios do $\mathrm{PE}$.

7.3. Tem-se defendido, por outro lado, que o êxito do euro dependerá do reforço da coordenação das políticas econômicas. Essa coordenação incumbe atualmente ao Conselho ECOFIN (a Comissão assegura o acompanhamento da evolução econômica dos Estados-Membros) e se concretiza por meio das orientações gerais de política econômica dos Estados-Membros (art. 99 TCE), do procedimento relativo aos déficits orçamentais excessivos (art. 104 TCE), do PEC e da Resolução sobre Crescimento e Emprego do Conselho Europeu de Amsterdã (arts. 125-130 TCE).

Em relatórios do PE tem sido advogada a conveniência de se trabalhar para um verdadeiro governo econômico europeu, que permita um melhor equilíbrio entre a política monetária e a política orçamental.

O PE tem também defendido a atribuição a si próprio de um papel mais ativo no que toca à definição das orientações gerais de política econômica (OGPE) e ao acompanhamento da supervisão multilateral (art. 99, n. ${ }^{\text {os }}$ 2, 3, 4 e 5 TCE).

Mas o PE tem realçado sobretudo a debilidade da União Econômica quando comparada com a União Monetária. Isso porque o PEC não passa de um apertado quadro limitador da política financeira e o Título VIII (Emprego) não parece ter força para quebrar as barreiras impostas pelo PEC e permitir a definição e execução de "uma estratégia coordenada na matéria de emprego", a não ser no que tange ao objetivo neoliberal de promover "mercados de trabalho que reajam rapidamente às mudanças econômicas” (art. 125 TCE).

É verdade que o TCE (art. $4 .^{\circ}$ ) aponta para a adoção de uma política econômica (dos Estados-Membros e da CE) "baseada na estreita coordenação da política econômica dos Estados-Membros" e estipula que “os Estados-Membros conduzirão as suas políticas econômicas visando contribuir para a realização dos objetivos da Comunidade, tal como se encontram definidos no art. 2." (art. 98). Em consonância com esses princípios gerais, o art. 99, n. ${ }^{\circ} 1$ determina que os Estados-Membros devem considerar as suas políticas econômicas como "uma questão de interesse comum”, o que dá sentido à conveniência da sua coordenação no Conselho e justifica a capacidade de, em certos termos, o Conselho aprovar orientações gerais das políticas econômicas. 
Essas orientações não são vinculativas (são simples recomendações) e a não compatibilidade das políticas econômicas adotadas pelos Estados-Membros com as OGPE recomendadas pelo Conselho (verificada por meio do referido processo de supervisão multilateral) apenas permite ao Conselho dirigir recomendações (eventualmente tornadas públicas) aos Estados-Membros que não sigam as OGPE.

O referido relatório da Comissão de Assuntos Institucionais sustenta que essa assimetria entre as vertentes econômica e monetária da UEM não pode continuar por mais tempo, porque prejudica a tomada das decisões necessárias por parte das instituições competentes em matéria de políticas econômicas (Conselho Europeu, Conselho ECOFIN, Comissão, Comitê Econômico e Financeiro), correndo-se o risco de, por omissão, a política da $\mathrm{CE}$ vir a ser a política do BCE, com o risco acrescido de que o BCE venha a definir políticas monetárias acentuadamente rigorosas, divorciadas dos problemas econômicos e sociais.

E não falta quem entenda que, na realidade, o BCE vem sacrificando tudo ao dogma monetarista da estabilidade monetária, em nome do qual se têm produzido males evitáveis e injustiças insustentáveis.

Por essas razões, tem-se defendido, no $\mathrm{PE}$, a necessidade de criar mecanismos que assegurem uma coordenação eficaz da política monetária com a política econômica, um maior equilíbrio de poderes institucionais e o controle democrático do BCE. Alguns documentos do PE falam mesmo da necessidade de uma "coordenação institucionalizada das políticas macroeconômicas", defendendo que a política monetária única requer alguma aproximação das políticas fiscais (Parecer do deputado Fernand Herman sobre o Relatório Barros Moura).

Na Resolução A4-0030/1999, o PE defende a urgência um acordo interinstitucional entre o PE, o Conselho e a Comissão que conduza à aplicação de "processos de tomada de decisões mais democráticos entre as instituições" no que respeita à formulação e aprovação das OGPE.

Defende também a necessidade de alargar o âmbito das OGPE às várias políticas macroeconômicas (políticas orçamentais, políticas tendentes à melhoria da produtividade e da competitividade, políticas estruturais relativas aos mercados de bens e serviços e da força de trabalho), propondo a alteração do art. 99 TCE de modo a criar um conjunto de políticas com objetivos vinculativos para os Estados-Membros.

Essa mesma Resolução defende o reforço da coordenação das políticas econômicas e sociais dos vários Estados-Membros e da $\mathrm{CE}$, de modo a viabilizar "uma política econômica coerente e eficaz na UE e nos seus Estados-Membros", a garantir "um debate público democrático (mediante o reforço da coordenação entre os parlamentos nacionais e o Parlamento Europeu) sobre as opções econômicas européias" e a "melhorar o processo decisional e reforçar a sua transparência.” E propõe que as OGPE sejam adotadas por uma decisão do Conselho (em vez da recomendação, como agora acontece) e que a supervisão multilateral seja exercida pelo Conselho Europeu, conduzindo a decisões vinculativas para os EstadosMembros que não respeitem as OGPE.

A Resolução do PE que vimos referindo defende peremptoriamente que "a inexistência de uma política económica e fiscal comum é 
totalmente incompatível com a gestão unificada da política monetária”, e, quanto à política fiscal, considera "desejável uma aproximação dos regimes fiscais dos EstadosMembros da zona euro, em particular no que se refere à tributação da poupança e ao imposto sobre as sociedades", apontando para soluções de tipo federalista ao defender que as decisões nessa matéria devem ser adotadas por maioria qualificada.

Vários autores vêm também apontando como inevitável a evolução para um maior federalismo em matéria de política fiscal, na exata medida em que o TCE e o PEC impedem os Estados-Membros de utilizar uma política fiscal contra-cíclica, com vistas a suavizar as crises econômicas: se os Estados-Membros o não podem fazer, tem de ser a Comunidade a assumir esse papel.

7.4. Como contrabalanço político da União Monetária, o PE vem defendendo uma União Econômica e Social, uma ordem social européia baseada numa "aproximação progressiva segundo o método dos padrões mínimos e da coordenação (por exemplo, legislação laboral, segurança social, luta contra a exclusão social, promoção do emprego)", sustentando que "o euro deveria incentivar os Estados-Membros a adoptar um mínimo de normas comuns que permitam evoluir no sentido de um verdadeiro modelo social europeu".
Nessa mesma Resolução do PE sublinha-se que "a construção de uma união econômica e monetária exige um sistema orçamental 'de inspiração federal' ou, pelo menos, um mecanismo institucional e financeiro que permita abordar uma situação de crise num ou em vários Estados-Membros". E defende-se que o financiamento futuro da UE “deve ser tratado em função do objectivo de coesão econômica e social".

Uma vez criada a moeda única (ela própria considerada uma 'exigência' do mercado único), de muitos lados começou a dizer-se que ela representava um salto importante no sentido da união política (há mesmo quem defenda que a união monetária 'obriga' a caminhar no sentido da união política).

Os partidos socialistas europeus defenderam recentemente (Público, 4 de outubro de 2002) a elaboração de uma Constituição Européia que substitua os Tratados atualmente em vigor. $\mathrm{E}$ algumas vozes defendem a evolução da UE para um estado federal.

Está-se, como se vê, perante um enorme conjunto de reflexões e de propostas que, independentemente da posição que se tenha sobre elas, não poderão ser ignoradas eternamente e cuja análise coloca, não só no nível da CE, mas também em todos os Estados-Membros, novos e delicados problemas institucionais e constitucionais e, sem dúvida, complicados problemas políticos. 